\title{
Parto Humanizado
}

Desde que Simpson, em 1847, usou o clorofórmio para mitigar as dores do trabalho parturiente, procurou-se abreviar e suavizar os sofrimentos relacionados com o parto.

Melhor interpretou-se o texto do Gênesis (cap. 4,16): "Eu multiplicarei os teus trabalhos e os teus partos. Tu em dor parirás teus filhos". Ficou patente a errônea e absurda interpretação exegética do texto bíblico não condizente com a Divindade onde o anátema, vingativo e retaliativo, não poderia jamais coadunar-se com os atributos de bondade e condescendência do Altíssimo.

Desde os tempos de Simpson a analgotocia, em todas as modalidades, é defendida e progressivamente aperfeiçoada para atendimento ao parto da mulher civilizada. O notável avanço no conhecimento da fisiologia da parturição possibilitou controle e menor sofrimento das gestantes na gravidez a termo e no parto. Foram estabelecidas rotinas seguidas por todos os centros obstétricos para atendimento ao Parto Humanizado.

No nosso entender, deveriam as Instituições Governamentais e outras investir nas entidades já existentes para melhor atender ao acima mencionado: Parto Humanizado.

Criaram-se as Casas de Parto com estrutura, filosofia e comando duvidosos no afã de reinventar o que já, há algumas décadas, era sobejamente conhecido, "nil novi sub sole", embora canhestramente praticado pela exigüidade de recursos.

O médico, ator relevante no cenário constituído, foi relegado e substituído ganhando realce figurantes coadjuvantes (obviamente também necessários) com prejuízo no atendimento à figura principal: A Gestante.

Enfim, o que desejamos? Malgrado interesses momentâneos, nem sempre acoplados com o fim colimado, todo o esforço deverá ser empregado para atendimento pré-natal de excelência tendo a gestante, na parturição, seu Parto Humanizado.

\section{A Diretoria}

